\title{
Title: Molecular characterization of Termitomyces protoclones through PCR and RFLP based DNA typing
}

Authors: Pijush Mallick ${ }^{1 *}$, Sobhan Roy Chowdhury ${ }^{2 *}$, Dipanwita Roy ${ }^{1}$, Subhash Kanti Roy ${ }^{2}$ and Sikdar $\mathrm{SR}^{1}$

Address: ${ }^{1}$ Division of Plant Biology, Bose Institute, P1/12, C.I.T., Scheme VII M, Kolkata 700054 India

${ }^{2}$ Deptartment of Biotechnology, Oriental Institute of Science \& Technology, Vidyasagar University, Dewandighi, Burdwan, West Bengal 713102 India

*Equal first authorship.

\begin{abstract}
A total of five protoclones were successfully cultured on PDA medium out of regenerated twenty two colonies of Termitomyces protoplast and further studied. Liquid MYG grown mycelial tissue is used for protoplast isolation by enzymatic digestionin a mixture containing Lysing enzyme 2\% and Cellulase R10 2\% in $0.6 \mathrm{M}$ mannitol. The incubation conditions like temperature, shaking and time were standardized at $24^{\circ} \mathrm{C}, 60 \mathrm{rpm}$ and 10 hours, respectively for healthy protoplasts liberation. The purified protoplasts showed an average yield of $1.2 \times 10^{7}$ cells/gm tissue with $31.60 \pm 9.31 \%$ regeneration efficiency on specific medium and $77.12 \pm 2.72 \%$ viability by FDA test. Four ISSR primers were used in this study resulting a total of 27 reproducible bands with mean value of 6.75 . They showed similar banding pattern in all the lines with zero percent polymorphism ranged from $280 \mathrm{bp}-2700 \mathrm{bp}$. The amplified rRNA-ITS gene showed $\sim 600$ bp size in gel and found a single restriction site for enzyme HaeIII in all the protoclones and parent with similar fragment size in all.
\end{abstract}

Keywords: DNA markers, Edible mushroom, Genome stability, Protoplast regeneration. 


\section{Introduction}

Edible mushrooms are rich in protein content and thus used as food supplement worldwide. They can be commercially cultivated but still the wild collection is very popular to the poor tribal family in Asian and African countries. Termitomyces $s p$. is such popular wild edible mushroom grown in termite gut and found in Birbhum, Purulia and Medinipur districts of West Bengal, India. Apart from protein, Termitomyces is an affluent source of sugar, fibre, lipid, vitamin, mineral in addition to medicinal value which is used in lower blood pressure, rheumatism, kwashiorkor, obesity, diarrhea and purgative [1-2]. So, it is now an important issue to improve the Termitomyces strains in terms of substrate specificity, yield and nutritional attributes. The mushroom crop improvement includes the two major aspects i.e., genome shuffling via protoplast fusion technology and development of transgenic via genetic engineering. Due to the lack of available genetic resources and many other disadvantages, researchers prefer the protoplast fusion technology for mushroom breeding where even mating can be possible between the sexually incompatible strains [3-4]. However, it has been proved that the protoplasts are good source material for mushroom crop improvement where researchers had successfully developed somatic hybrids between the different genera followed by fruit body production [3-5]. Development of Termitomyces protoplast and study about their genome stability is a crucial factor for somatic breeding with other genera. Sometimes, the fruit body derived mushroom strains show genome instability with their parent analyzed by molecular DNA markers [6].

In the past, few Chinese mushroom researchers developed protoclones of Agaricus bisporus and characterized them using morphological and molecular parameters [7]. They showed the genome instability in the protoclones analyzed by ISSR markers. ISSR is a reproducible molecular DNA marker for genetic analysis [8] and hence have been used to study the genetic diversity of mushrooms $[3-4,7,9,10]$. The RFLP of nuclear rRNA-ITS genes are also productive molecular markers for mushroom genome analysis [4, 16]. However, in this study we wanted to study about the genome stability of Termitomyces heimii protoclones developed from mycelial tissues and characterization by productive molecular DNA markers.

\section{Materials \& methods}

\subsection{Protoplast isolation, purification and culture}

Fruit body of Termitomyces heimii was collected from Bankura district of West Bengal, India and routinely maintained the vegetative culture on PDA medium (Potato 
Dextrose Agar, $\mathrm{pH} 6.2)$ at $28^{\circ} \mathrm{C}$. The 7 days old MYG $(10 \mathrm{~g} / 1$ malt extract, $4 \mathrm{~g} / 1$ yeast extract and $10 \mathrm{~g} / 1$ glucose, $\mathrm{pH}$ 6.2) grown mycelial tissue used for enzymatic digestion. Protoplast isolation and purification was carried out according to the protocol of Mallick \& Sikdar [3]. Protoplast yield was measured using a hemocytometer and viability was calculated by FDA staining [11]. Culture media containing MYG supplemented with $0.7 \mathrm{M} \mathrm{NaCl}$ as an osmotic stabilizer and $1.5 \%$ agar with purified protoplast was kept at $28^{\circ} \mathrm{C}$ for regeneration.

\subsection{Extraction of genomic DNA and ISSR}

The genomic DNA was extracted from MYG grown mycelial tissues using modified $C T A B$ method [12]. Four ISSR primers were used (Table1) in each single reaction according to the protocol of Bornet \& Branchard [8] with slight modifications. The PCR was performed in $25 \mu 1$ of reaction volume in a DNA thermal cycler (Applied Bio-systems 2027) containing 25ng template DNA, 10X Taq buffer $(+\mathrm{KCl}), 25 \mathrm{mM} \mathrm{MgCl}_{2}, 2 \mathrm{mM}$ dNTPs mix, primer and Taq DNA polymerase $(5 \mathrm{U} / \mu \mathrm{l})$. The initial denaturation at $94^{\circ} \mathrm{C}$ for $5 \mathrm{~min}$, followed by 40 cycles consisting of denaturation at $94^{\circ} \mathrm{C}$ for $1 \mathrm{~min}$, primer annealing $\left(37-61^{\circ} \mathrm{C}\right)$ for $1 \mathrm{~min}$ and extension at $72^{\circ} \mathrm{C}$ for $3 \mathrm{~min}$ and a final extension for $10 \mathrm{~min}$ at $72^{\circ} \mathrm{C}$.

\subsection{Amplification of rRNA-ITS gene and RFLP}

According to the protocol of White et al. [13], the rRNA-ITS gene was amplified by $\mathrm{PCR}$ in a $25 \mu \mathrm{l}$ of reaction volume containing $15 \mathrm{ng}$ template DNA, 10X Taq buffer $(+\mathrm{KCl})$, 25mM $\mathrm{MgCl}_{2}, 2 \mathrm{mM}$ dNTPs, primer ITS1-F(5' TCCGTAGGTGAACCTGCGG 3') and ITS4-

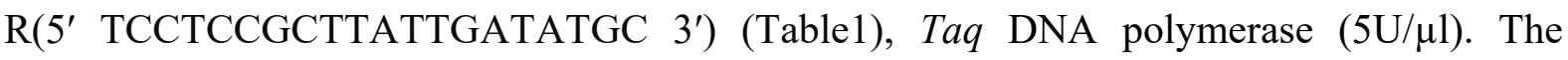
amplification was conducted in a DNA thermal cycler (Applied Bio-systems 2027) by preliminary denaturation at $95^{\circ} \mathrm{C}$ for 4 min followed by 40 cycles; denaturation at $94^{\circ} \mathrm{C}$ for 1 min, primer annealing at $55^{\circ} \mathrm{C}$ for $1 \mathrm{~min}$, initial extension at $72^{\circ} \mathrm{C}$ for $1 \mathrm{~min} 30 \mathrm{sec}$, followed by a final extension at $72^{\circ} \mathrm{C}$ for $8 \mathrm{~min}$. For restriction analysis, PCR products were purified by sodium acetate precipitation. $10 \mu \mathrm{l}$ of purified PCR product was used for restriction digestion according to the supplier's specification with enzyme HaeIII (Fermentas).

\subsection{Gel electrophoresis}

ISSR fragments, rRNA-ITS products and restriction digested products were separated on $1.8 \%, 1.5 \%$ and also $1.5 \%$ agarose gel with pre-stained ethidium bromide solution using 1X TAE buffer, respectively. The gels were run at 80 volts for 3 hrs (ISSR), 2 h (rRNA-ITS) 
and $3 \mathrm{~h}$ (RFLP) and banding profiles were visualized under UV light using a transilluinator system. Data were recorded in a Molecular Analyst Gel Documentation System. Gene Ruler 100 bp plus DNA ladder, (MBI, Fermentas) is used as a standard molecular weight marker in each case. [Table1 near here]

\section{Results}

\subsection{Protoplast culture and regeneration}

The enzyme mixture containing lysing enzyme $2 \%$ and cellulase R10 2\% in $0.6 \mathrm{M}$ mannitol as osmoticum showed the best result with gentle shaking at $60 \mathrm{rpm}$ for 10 hat $24^{\circ} \mathrm{C}$. The average yield of purified protoplast was $1.2 \times 10^{7}$ cells/gm of 7 days old tissues (Fig.1a) as optimum. They showed the maximum $31.60 \pm 9.31 \%$ regeneration and $77.12 \pm 2.72 \%$ viability (Fig.1c). The purified protoplasts (Fig.1b) were cultured on MYG medium supplemented with $0.7 \mathrm{M} \mathrm{NaCl}$ and $1.5 \%$ agar, $\mathrm{pH} 6.2$ and kept at $28^{\circ} \mathrm{C}$ for regeneration. Protoplast started germ tube formation in $24 \mathrm{~h}$ followed by micro-colonies (Fig.1d) formation in $72 \mathrm{hrs}$ onwards. A total of twenty two macro-colonies were observed in four replicate regeneration plates after 5, 7 (from two replicate) and 8 days, respectively. Immediately, the colonies were transferred in PDA mediumfor further growth and kept at $28^{\circ} \mathrm{C}$. Among them only five putative protoclones were selected based on their growth performance and named as TPC1, TPC2, TPC3, TPC4 and TPC5 (Fig.1e\&f).

\subsection{ISSR profile}

Four reproducible ISSR primers amplified a total of 27 bands in all the TPC lines including parent with mean value of 6.75. ISSR-01 produced the lowest number of band i.e., 5 and ranged from $520 \mathrm{bp}-1850 \mathrm{bp}$ where ISSR-12 produced the highest number of band i.e., 9 and ranged from $280 \mathrm{bp}-2700 \mathrm{bp}$ (Table1). All the TPC lines showed similar banding patterns in size and number with the parentusing ISSR primers (Fig.2). However, the ISSR profiles resulted that there is no dissimilarities or polymorphism inall the protoclones with respect to their single parent.

\subsection{Amplification of rRNA-ITS region and RFLP analysis}

The primer set ITS1(F) and ITS4(R) amplified the rRNA-ITS gene in all the TPC lines and parentand the size was analyzed in agarose gel. The PCR product showed a single band in all the lines with approx. $600 \mathrm{bp}$ in size (Fig.3a). The primer set ITS1(F) and ITS4(R) can amplify only the ITS1-5.8S-ITS2 region which is basically a conserved sequence. We 
also found that the TPC lines are genetically similar with the parent bythe restriction enzyme digestion. Restriction enzyme HaeIII showed only single restriction site in the entire ITS15.8S-ITS2 region in all the lines including parent (Fig.3b). It was also noted that the sizes of restriction fragments were same in all.

\section{Discussion}

Development of protoclones of agricultural crop usually helps in breeding for development of superior quality lines. In plant system several reports have been made where protoclones are developed from the protoplast and interestingly they showed phenotypic diversity where genotypic identity was maintained and vice-versa [14-15]. Theoretically, protoclones are identical lines of the existing parent whether it may be plant, animal, fungi or other living organisms. For rapid multiplication of crop plant and mammalian cell lines this technique is used in tissue culture industry.

Reports on characterization of mushroom protoclones are limited and it depends on the regeneration percentage of protoplast in the suitable culture medium. Isolation and purification of Termitomyces protoplast was carried out following the standardized protocol with slight modifications and the protoplasts were cultured in such suitable medium where the regeneration percentage was highly achieved. However, the resulted genetic structures were identical in all the TPC lines with parent based on ISSR profile and RFLP of rRNA-ITS gene. The ISSR, RFLP of rRNA-ITS gene has already been proved as reproducible and suitable genetic markers for analysis of mushroom somatic hybrids and fruit body derived lines $[3-4,16]$. Even the mushroom fruit body derived lines showed genetic diversity which might be occurred due to the gene environmental factor followed by elimination or rearrangement of genome structure during subsequent culture (Mallick \& Sikdar, 2015). In this case, all the TPC lines are genetically identical with little morphological dissimilarity like heterogeneous colony nature, growth rate on PDA medium (not details in this manuscript). This might be happen due to the presence of inactive compounds in the medium or the protoplast cultures were not exposed to the environment where direct gene environmental factor works. The morphological variation maybe due to the effects of vegetative culture or the growth responsive gene might be in the dominant allele or induced during sub-culturing.

Protoplast technology is very useful technique for mushroom crop improvement specially when it is essential to develop somatic hybrid between two sexually incompatible strains. In mushroom crop breeding there are still lacks of genetic resources and hence 
transformation is restricted. However, principally it is essential to be identical the protoclones so that they can be used as stable genetic material for transformation. Mushroom protoplast can be used for gene transformation having stable genetic makeup in future research. In this manuscript we have successfully standardized the Termitomyces's protoplast isolation, purification and culture. We have also showed the homokaryotic nature of each protoclones with single parent. However, in this study we have identified the similar banding profiles through ISSR and RFLP of rRNA-ITS gene in all the protoclones with parent. As they are derived from the protoplasts, the genetic makeup remains identical in this case and we could claim that these lines are identical clone of a single parent i.e., Termitomyces. The further study regarding their yield at field level, detail genetic attributes by FISH, nutritional profiles of the existing cloud give a good conclusion.

\section{Acknowledgement}

We are thankful to the Director of Bose Institute and Head, Division of Plant Biology section for providing all the necessary facilities and support.

Conflicts of Interest: The authors don't have any conflict of interest.

\section{References:}

1. Apetorgbor, M.M.; Apetorgbor, A.K.; Nutakor, E. Utilization and cultivation of edible mushrooms for rural livelihood in Southern Ghana. The $17^{\text {th }}$ Commonwealth Forestry Conference, Colombo, Sri Lanka, 2005.

2. Rajoriya, A.; Tripathy, S.S.; Gupta, N. Nutritional and biochemical characterizations of different parts of Termitomyces eurrhizus from the Odisha. Int. J. Phytotherapy. 2014, 4, 136-138.

3. Mallick, P.; Sikdar, S.R. Production and molecular characterization of somatic hybrids between Pleurotus florida and Lentinula edodes. World J. Microbiol. Biotechnol. 2014, 30, 2283-2293.

4. Mallick, P.; Sikdar, S.R. Fruit body production and characterization of hybrid edible mushroom strains developed by protoplast fusion between Pleurotus florida and Lentinus squarrosulus. Int. J. Pharma BioSci. 2015a, 6, 301-314. 
5. Chakraborty, U., Sikdar, S.R. Intergeneric protoplast fusion between Calocybe indica (milky mushroom) and Pleurotus florida aids in the qualitative and quantitative improvement of sporophore of the milky mushroom. World J. Microbiol Biotechnol, 2010, 26, 213-225.

6. Mallick, P.; Sikdar, S.R. Genome instability in fruit body derived lines generated from fruiting pfle somatic hybrid lines and development of hybrid strain specific SCAR marker in edible mushroom. J. Hort. Res. 2015b, 23, 111-120.

7. Nazrul, M.I.; Yin-Bing, B. ISSR as New Markers for Identification of Homokaryotic Protoclones of Agaricus bisporus. Current Microbiol, 2010, 60, 92-98.

8. Bornet, B.; Branchard, M. Nonanchored Inter Simple Sequence Repeat (ISSR) Markers: Reproducible and Specific Tools for Genome Fingerprinting. Plant Mol. Bio. Rep. 2001, 19, 209-215.

9. Guan, X.J.; Xu, L.; Shao, Y.C.; Wang, Z.R.; Chen, F.S.; Luo, X.C. Differentiation of commercial strains of Agaricus species in China with inter-simple sequence repeat marker. World J. Microbiol. Biotechnol. 2008, 24, 1617-1622.

10. Malekzadeh, K.; Shahri, B.J.M.; Mohsenifard, E. Use of ISSR markers for strain identification in the button mushroom, Agaricus bisporus. Proceedings of the $7^{\text {th }}$ International Conference on Mushroom Biology and Mushroom Products (ICMBMP7), 2011, 30-34.

11. Widholm, J.M. The use of fluorescein diacetate and phenosafranine for determining viability of cultured cells. Stain Technol. 1972, 47, 189-194.

12. Dellaporta, S.L.; Wood, J.; Hicks, J.B. A plant DNA minipreparation: version II. Plant Mol. Bio. Rep. 1983, 1, 19-21.

13. White, T.J.; Bruns, T.; Lee, S.; Taylor, J. Amplification and direct sequencing of fungi ribosomal RNA genes for phylogenetics. In: Innis, M.A.; Gelfand, D.H.; Sninsky, J.J.; White, T.J. (eds) PCR protocols. A guide tomethods and applications. Academic San Diego, 1990, pp 315-322.

14. Gill, B.S.; Kam-Morgan, L.N.W.; Shepard, J.F. Origin of chromosomal and phenotypic variation in potato protoclones. J. Heredity, 1986, 77, 13-16.

15. Kane, E.J.; Wilson, A.J.; Chourey, P.S. Mitochondrial genome variability in Sorghum cell culture protoclones. Theor.Appl.Genet. 1992, 83, 799-806.

16. Mallick, P.; Sikdar. S.R. Restriction fragment length polymorphism and sequence analysis of rRNA-ITS region of somatic hybrids produced between Pleurotus florida and Lentinula edodes. Ann. Microbiol. 2016, 66, 389-395. 


\section{Figures:}
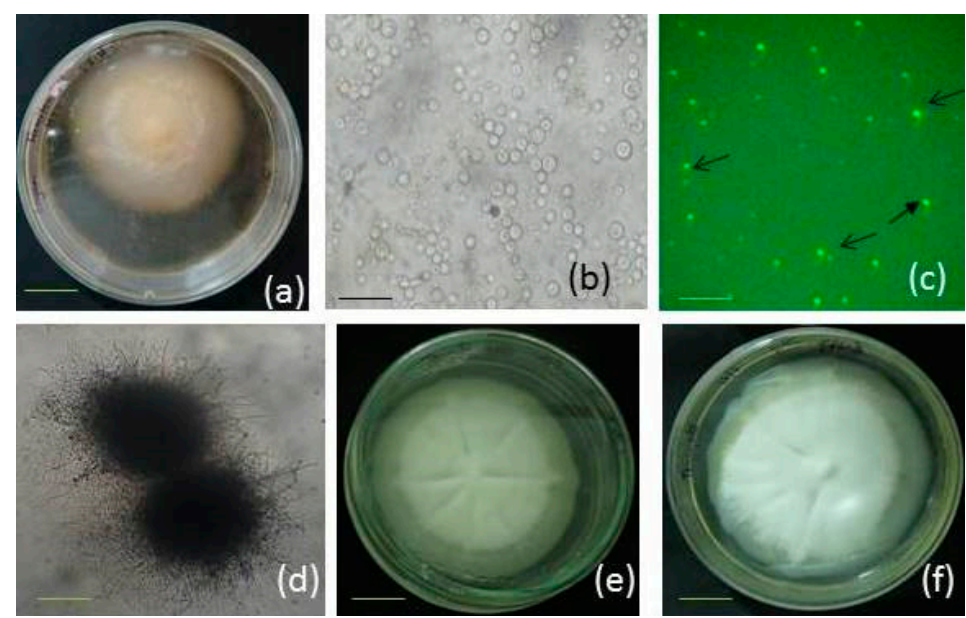

Figure 1. (a) 7days old liquid culture of Termitomyces, (b) Purified protoplasts in $0.6 \mathrm{M}$ mannitol isolated from liquid-grown tissue, (c) FDA stained viable protoplasts, (d) Developed 3 days old micro-colonies on regeneration medium, (e) 7days old PDA culture of TPC1, (f) 7days old PDA culture of TPC5. Bar size: 20mm in (a), (e) \& (f). $60 \mu \mathrm{m}$ in (b), 100 $\mu \mathrm{m}$ in (c) and (d)

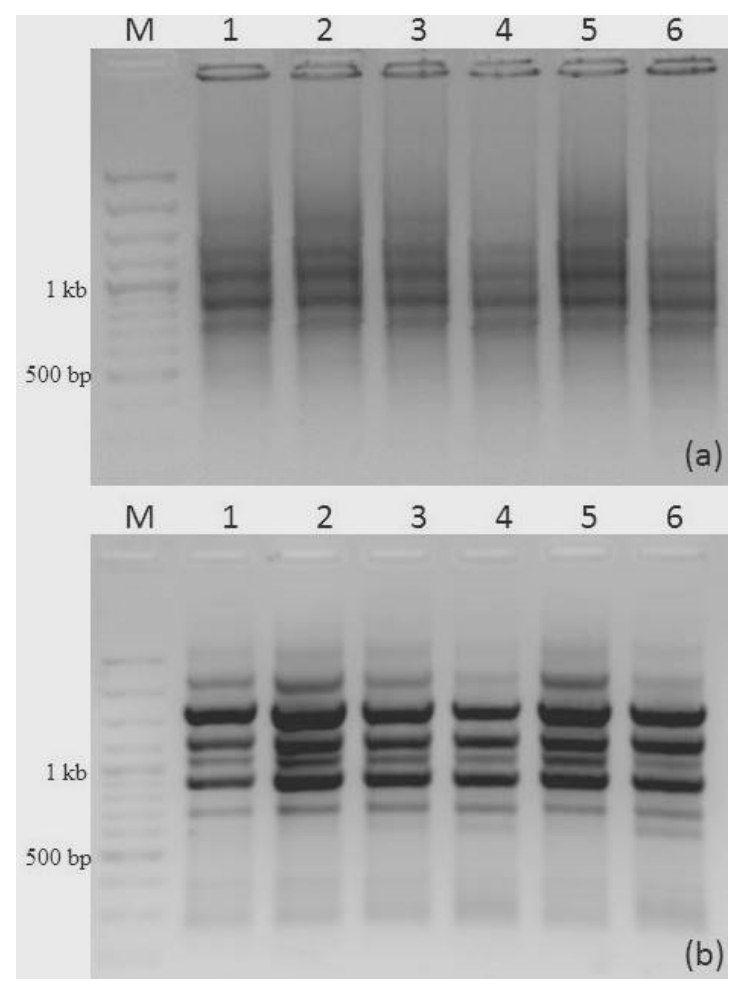

Figure 2. ISSR profiles of TPC cultures and parent Termitomyces generated by (a) ISSR-11 and (b) ISSR-12. Lanes: M - molecular weight markers, 100 bp DNA ruler plus, lane1parent Termitomyces and lane $2-6$ is TPC $1-5$, respectively. 


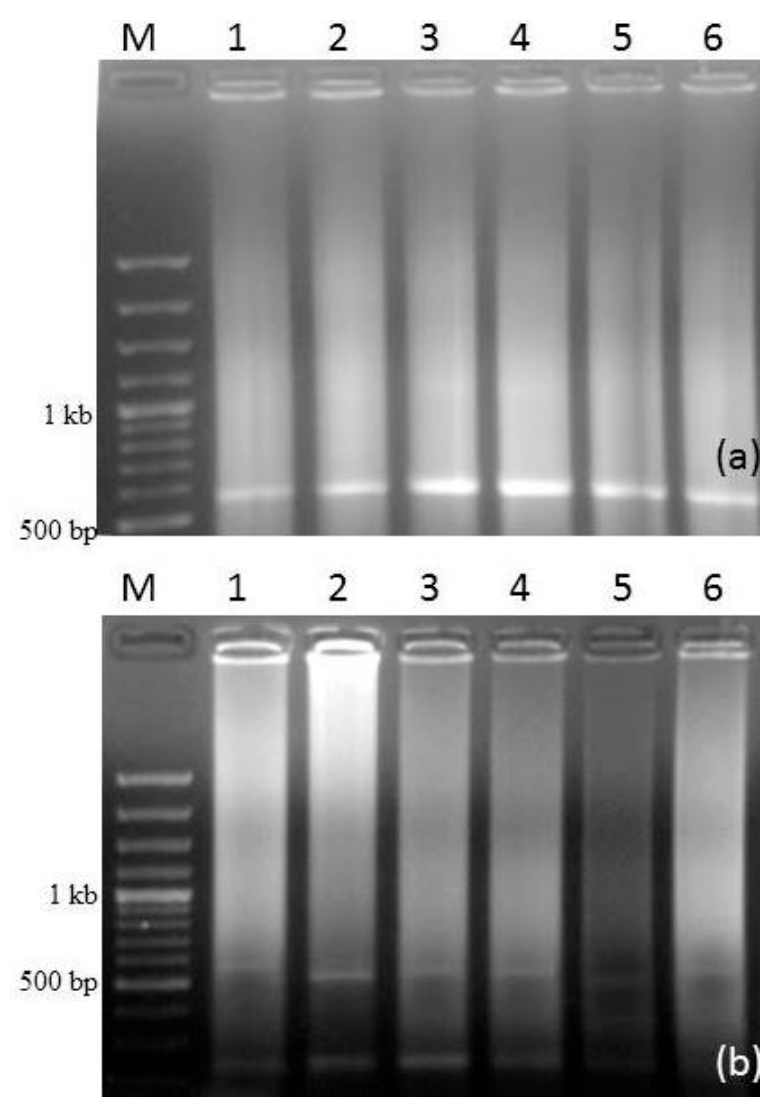

Figure 3. The rRNA-ITS gene and RFLP profile of TPC lines and parent Termitomyces. (a) Amplified rRNA-ITS gene showing approx. 600 bp size in gel, (b) RFLP profile by restriction enzyme HaeIII. Lanes: M - molecular weight markers, 100 bp DNA ruler plus, lane 1 - parent Termitomyces and lane $2-6$ is TPC $1-5$, respectively. 
Table1: Details of primers used in this study.

\begin{tabular}{|c|c|c|c|c|}
\hline S1 No. & $\begin{array}{l}\text { Primer } \\
\text { Name }\end{array}$ & $\begin{array}{l}\text { Sequence }\left(5^{\prime}-3^{\prime}\right) \\
\text { with repeat motif }\end{array}$ & $\begin{array}{c}\text { No. of } \\
\text { amplified } \\
\text { bands }\end{array}$ & $\begin{array}{l}\text { Size range in } \\
\text { bp }\end{array}$ \\
\hline 1. & ISSR-01 & $\begin{array}{l}\text { GACAGACAGACAGACA } \\
\text { [(GACA }) 4]\end{array}$ & 5 & $520-1850$ \\
\hline 2. & ISSR-02 & $\begin{array}{c}\text { CAGCAGCAGCAGCAG } \\
{[(\mathrm{CAG}) 5]}\end{array}$ & 7 & $350-2200$ \\
\hline 3. & ISSR-11 & $\begin{array}{l}\text { CACCACCACGC } \\
{[(\mathrm{CAC}) 3 \mathrm{GC}]}\end{array}$ & 6 & $500-2000$ \\
\hline 4. & ISSR-12 & $\begin{array}{c}\text { GAGGAGGAGGC } \\
{[(\mathrm{GAG}) 3 \mathrm{GC}]}\end{array}$ & 9 & $280-2700$ \\
\hline 5. & $\begin{array}{l}\text { ITS1-F } \\
\text { ITS4-R }\end{array}$ & $\begin{array}{l}\text { TCCGTAGGTGAACCTGCGG } \\
\text { TCCTCCGCTTATTGATATGC }\end{array}$ & 1 & 600 \\
\hline
\end{tabular}

